\title{
Roma, Curriculum, and Textbooks: The Case of Greece
}

\author{
Dimitris T. Zachos \\ Faculty of Education, School of Primary Education, Aristotle's University of Thessaloniki, Thessaloniki, Greece \\ Email: dimzachos@eled.auth.gr
}

How to cite this paper: Zachos, D. T. (2017). Roma, Curriculum, and Textbooks: The Case of Greece. Creative Education, 8, 1656-1672.

https://doi.org/10.4236/ce.2017.810112

Received: June 16, 2017

Accepted: August 13, 2017

Published: August 16, 2017

Copyright (C) 2017 by author and Scientific Research Publishing Inc. This work is licensed under the Creative Commons Attribution International License (CC BY 4.0).

http://creativecommons.org/licenses/by/4.0/

\begin{abstract}
The aim of this paper is to search out the educational problems that students of Roma origin confront, especially those coming from institutional arrangements and laws. Toward this end, we undertook a content analysis of all of the textbooks currently used in Greek primary education. Our research showed that, despite their improvement, the "new" textbooks continue to treat Greeks as the center of interest in education. The weak presence of Roma in textbooks renders the imperative need for a curriculum which explores issues of social inequality and injustice; a curriculum which will set forth the problems, activities, and accomplishments of all portions of the population, independent of class, ethnic or national origin, sex, sexual orientation or special needs.
\end{abstract}

\section{Keywords}

Roma Education, Greece, Curricula, Textbook

\section{Introduction}

The object of this paper is to investigate the educational problems that students of Roma origin confront, especially those coming from institutional arrangements and laws. More precisely, this study is based on research aimed at investigating the "image" of Roma presented in Greek curricula and textbooks.

Several different social groups living throughout continental Europe and America which share certain common historical and cultural elements are called Roma (Zachos, 2011a). In almost every place they live in, Roma groups suffer discrimination and racism that leads inevitably to their marginalization and exclusion from normal social life (Zachos, 2012). Their history, lower social status, and experience of discrimination and racism place Roma in a position similar to that of African Americans in the United States of America (Miskovic, 2009).

Roma education is a distinct part of what is called intercultural education- 
the wider category of theoretical and research activity which has as its central concern the way education can confront issues arising from the presence in the same classroom of students from different cultural backgrounds. There have been many folkloric, musicological, historical, and linguistic studies of the life and activity of the Roma but there has been no corresponding research activity examining their education. The relevant research output is rather poor in comparison to the great wealth of existing research literature concerning the education of migrants and other minorities in Europe and North America (New \& Merry, 2012).

Any attempt to record the educational problems children of Roma origin face as well as any proposed solutions must, in our opinion, always begins from their lived everyday life and experience. Roma students' schooling and more generally the schooling of all children from low socioeconomic backgrounds is affected by their economic and social status. Socioeconomic statuses, namely parental income and level of education (Schmid, 2001), are crucial factors in students' success or failure in school. There is a strong connection between educational success and economic disadvantage (Coley \& Baker, 2013). People living in poverty are more likely to not have adequate resources to support their children's schooling (buying books, computers, additional private tutoring). They also lack comfortable housing, separate rooms for their children, proper nutrition, or even basic amenities such as running water and electricity. Roma often live in poor sanitary conditions, close to sources of air or sound pollution (Levinson, 2005). Poverty often drives a portion of Roma children to have to work as well (Halkiotis, 2000).

Furthermore, students coming from low socioeconomic backgrounds lack cognitive stimulation from their family and social experiences from their preschool years which research has shown to be one of the most common causes of failure in school (Freeman, Brookhart, \& Loadman, 1999). These squalid living conditions diminish their interest in school (Politou, 1996).

The educational and social integration of the members of Roma groups is also connected to the way in which local governments and societies have historically treated them. As we already mentioned, in most countries, for centuries Roma has faced discrimination and persecution and has lived in social exclusion. Furthermore, Roma groups' and individuals' contribution to socioeconomic life is not recognized and their culture is underestimated-a situation also reflected in formal education.

Historically, education has played a central role in the formation of national identity in western nation-states and the assimilation of ethnic/national/cultural minorities. Educational systems legitimate national culture and erase diversity (Gellner, 1983). In order to accomplish this aim, official educational systems have ignored those portions of their populations whose members are distinguished from the "majority" group by features such as language, religion, manners and customs.

However, the past thirty years have seen the development of what has been 
called "identity politics", which has pushed the education systems of a number of western countries to abandon the politics of assimilation and to seek the integration of students with different ethnic and cultural backgrounds. This new politics has brought with it changes to national curricula and consequently changes also to the everyday activities of educators.

The present paper belongs to a series of studies by the author (Zachos, 2007; 2011a; 2011b; 2012; 2014; 2017; Zachos \& Panagiotidou, 2016) which attempt to examine the relationship of Roma groups living in Greece to the national education system. More specifically, the present study examines the way in which Roma groups are presented in the official curriculum and textbooks used in Greek primary education.

\section{Roma and the Curriculum}

A curriculum is a guide for lesson planning which includes general goals, course materials, the duration of studies, as well as descriptions of various other student activities (Flouris, 1983). A curriculum does not simply define the knowledge which students will be required to possess but it also defines the educator's activity during the educational process (Conell, 1992). In other words, a curriculum is an organized way of teaching, a tool, which the educator uses in his/her everyday practice as a kind of professional compass that explains what he/she needs to do and when to do it (Vrettos \& Kapsalis, 1999).

The content and structure of the curriculum constitutes one of the most controversial issues in education. The basic questions of this discussion relate to: First, whether and to what extent there is knowledge which must be mastered by all students; second, who gets to choose what knowledge is included in the curriculum? If we assume that a common curriculum is necessary, then we will have to answer the following questions:

- What knowledge is most valuable to whom and why?

- Whose interests does it serve?

- How can we organize knowledge so that is conveyed most effectively to every student?

- Whether and to what degree curriculum should be differentiated to correspond to the variety of student interests and levels of motivation?

The body of knowledge finally covered by the curriculum is that which has recognition from political authority, the state. It is "official knowledge" (Apple, 1993) which helps the ruling class perpetuate its position of power and institutionalizes societal inequalities (McCarthy, 1994). This is also why the content of the official national curricula is not acceptable to all who have an interest in the matter. There are serious objections to the image of the world presented in the curriculum and the specific cultural model it promotes. The most important objections are raised for the following reasons: 1) the curriculum ignores social conflicts and differences. 2) The curriculum tries to produce a common identity (common cultural models, convictions and values) (Beck, 1996) that devalues those of minority groups (Banks, 1975). 3) Historical information about the 
various different ethnic groups is either entirely absent or present only in very limited form (North, 2006). 4) There is no reference in the curriculum to the experiences of different peoples (Hickling-Hudson \& Ahlquist, 2003).

In Greece, there is central state control over the curriculum and school textbooks (Zambeta, 2000). The school curriculum is uniform, national and compulsory; there are standard hours, content and textbooks dictated by the Ministry of Education for all levels of schooling (Ifanti, 2008). We should note here that in the case of Greece, specific historical conditions engendered a framework which even today makes changing topics considered "national" by most politicians and reporters difficult (Zachos, 2009). Indicative of this situation is how only a very small number of schools implemented the legislation giving them the ability to teach about the cultures of children from minority groups (Law 2413/1996). As a result, in Greece, as well as in other countries, cultural elements of Roma groups (language, culture, and history) remain absent from school curricula (Kyuchukov, 2000; Cudworth, 2008; Sykora et al., 2010) or are undervalued (Lloyd \& Stead, 2002; Messing, 2008) or are distorted because the Roma are presented as a rebellious "tribe" which refuses to comply with the demands and commitments of modern life.

While in many countries mother-tongue education has already introduced to schools (Benson, 2004), in Greece, no schools teach Romani (Tsiakalos, 2008). This has great significance for whether Roma children succeed in the classroom or not since most are bilingual. Their native language is different from their school's dominant language of instruction. According to the prevailing research (Cummins, 1999), the teaching of a child's mother tongue positively influences the development of the child's linguistic competence and thus reinforces his/her ability to learn a second language. Additionally, the acceptance and recognition by the school of a key element of students' culture, language, contributes to self-esteem and self-confidence (Cummins, 1999).

However, we must note that the issue of Romani instruction in Greece is complex for the following reasons:

First, due to the fact that the Roma population is "extremely diverse" (Guy, 2009: p. 5) often speaking different languages (Zachos, 2011a) and dialects (Hatzisavidis, 2007). Even if the Greek state were to decide to create a written Romani language which could be taught in schools where children of Roma origin attend, it would not sufficiently address the issue at hand since the problem of dialect would remain; we do not even know which dialect of Romani is most widely spoken in Greece because there are no official records.

Second, there are no educators who can teach Romani.

Third, the representatives of the Greek Roma Organizations have not yet declared the need for teaching the Romani language in Greek schools, and are generally opposed to any action will yield their status as Minority Groups (No name author, 2005; Dimitras, 2000; Rougheri, 1999). This position is not as strange as it may seem if one considers the fact that in Greece, language defines who belongs to the Greek nation while non-Greek speakers are considered to be 
"others" (Mantouvalou, 2009). Greek Roma Organizations want to avoid minority status and the stigma that accompanies it. Indicative of the situation is the case of the municipality of Iraklia in the prefecture of Serres which in 2001 was forced to leave the Panhellenic Intermunicipal Network for the Support of Greek Roma Citizens because a portion of its residents reacted against the appellation Roma used in the relevant texts and refused to accept "exchanging History for a handful of millions" - the money set aside for the residential establishment of the area's Roma population (Stamatopoulos, 2001). The only official request for teaching Romani in some Greek schools was made in Western Thrace by Xarchakos (2001), a representative of the conservative party (New Democracy) in the European Parliament. However, this action is better understood as part of ongoing international antagonism between Greece and Turkey. Some human rights organizations which favor the political recognition of Roma's minority status have also requested the teaching of Roma language and history.

\section{School Textbooks in Greece}

School textbooks are a means of instruction, key tools for teachers and students, since daily instructional practice relies on them, but also as a part of extracurricular activities. Textbooks in Greece are based on the curriculum and provided free-of-charge to all students attending public schools. They occupy a fundamental role in the educational process and their content determines with precision the order in which subjects are presented in the new curriculum (Koustourakis, 2007). Furthermore, school textbooks exercise great influence on how students conceive of the natural and social world, especially in subjects such as history, language and geography where they can critically influence the way young students' understanding.

School textbooks enjoy an authoritative status, not only as a literary form (the power of the written word) but also as the official version of reality (Hamilakis, 2003). Textbook's ability to instill certain attitudes, convey values, and models of behavior related to the emotional sphere of personality and to influence views, convictions, and choices as well as individual behavior, have not been a matter of indifference to researchers (Xochellis, 2008).

From the period following the seventeenth dictatorship (mid 1970s) until the end of the 1990s, the Greek school curricula remained almost the same (Kouloumparitsi, 2005). There have been a number of studies investigating the ideological (Kapsalis \& Charalampous, 2008) political, social, and cultural messages that school textbooks pass on to their readers. Some researchers (Millas, 1991; Frangoudaki \& Dragonas, 1997) found that ethnocentric elements dominate the Greek national curriculum and school textbooks. The Greek nation's cultural characteristics are presented as if they have never been influenced by any other civilization, but as if Greek culture and history served exclusively as sources of civilization for other nations (Demertzis, 1995). According to this prevailing approach, the impact of another culture could only have negative effects on the 
Greek “self” (Diamantopoulou et al., 1995). Notably, Greek curriculum and textbooks main concern is to present the timeless continuity of the Greek nation. Language, religion, customs and traditions dominate the curriculum in order to prove the continuity of Greek national identity through time (Mponidis, 1998). Therefore, textbooks refer almost exclusively to the history of the country, while making only very fleeting and eclectic references to ancient civilizations and Europe (Zambeta, 2000). Only a relatively small part of the content contained in textbooks concerns itself with the non-Greek world, and even in those cases, people of different national/ethnic/cultural background are only used as a way to confirm the uniqueness of Hellenism or are grossly ignored in other cases (Ivrideli, 2001).

A series of factors such as the reformulation of the international economic and political landscape, the orders of the European Union, the country's economic growth, and the improvement of Greece's relations with Turkey and Bulgaria all resulted in changes to the goals in the curriculum and school textbooks. So, in 2003 introduced a series of major changes to the curricula. The 2003 curricula, with some minor changes, are still valid today. Among the targets of the current curriculum are attempts to develop awareness of European identity and citizenry; rejection of one-dimensional cultural models and the necessity of combating the phenomena of xenophobia and racism (Pedagogical Institute, 2001a: p. 2). The current curriculum stresses that "equality in education must be guaranteed for all students, especially those who belong to 'minorities"” (Pedagogical Institute, 2001a: p. 3). It also stresses the necessity of accepting cultural diversity, as well as the need for living together harmoniously in an environment of cultural, ethnic and linguistic diversity (Pedagogical Institute, 2001a: p. 4). The need for peaceful coexistence between different people and respect for their cultures and traditions has been incorporated into the history curriculum ( $\mathrm{Pe}$ dagogical Institute, 2001b: p. 1-2).

The authors of the textbooks that are now in use, which were written to implement the guidelines of the current curriculum, tried to introduce some multicultural elements. Thus, in these textbooks, there are pictures of children and adults of non-Greek nationalities/ethnicities and fairytales from other cultures. These changes were not met without reaction; the strongest prompting the withdrawal of the sixth-grade History book because of nationalist opposition (Zachos \& Michailidou, 2014).

\section{Methodology}

Our study had as its aim the investigation of a specific aspect of the way in which the Greek education system deals with members of Roma groups: Their "image" in the curriculum and in the textbooks. The basic question of our research concerned the frequency of appearance and the manner of presentation of Roma in school textbooks for students and teachers in Elementary School at all levels. Before beginning the study, we hypothesized that the presence of nationally, ethnically, and culturally different people and groups in Greek textbooks would 
be "visible to the naked eye". We expected our hypothesis to be confirmed and especially in the case of Roma groups who occupy the unique position of having an historical presence in areas that today belong to the Greek state exceeding a thousand years (Zachos, 2007).

Content analysis as a research method served the purpose of our study best. "Content analysis is any technique for making inferences by objectively and systematically identifying specified characteristics of messages" (Holsti, 1969: p. 14). The simplest form of content analysis is the counting of words (Krippendorf, 1980), sentences, idioms, paragraphs, articles, or corresponding texts. Through analyzing patterns of these elements (words, phrases, etc), we can reveal underlying meanings and ideas (Bowen \& Bowen, 2008). We chose content analysis, because it includes both qualitative and quantitative elements: It counts words, but it also looks for their meaning.

Our research was conducted in April 2017. We examined one hundred and seventy-four (174) textbooks currently used in primary education (Table 1). The digital versions of books gave us the ability to analyze all the textbooks instead of relying on a "sample". Textbooks were susceptible to examinations using keyword searches (Roma, Tsigganes, Gypsies).

Each word, sentence, phrase, paragraph, text or image related to Roma was a recording unit. The categories for analysis were:

1) Number of references

2) Extent of references: short or long texts

3) Character of the references: positive or negative

4) Manner of description: How are the Roma portrayed and how their relations with members of the other ethnic groups in Greece described.

To ensure the reliability of our research (Intercoder Reliability), two coders were used whose investigation brought about results identical to our own.

\section{Research Results}

\section{Number of references}

The results of our study showed that references to Roma groups are very rare. There are only two texts that have the name Tsiggana/oi (Roma) in their title: "Oi filoi mas Tsigganoi" (Our friends Roma) by Helen Sarantiti and "I kalogria I

Table 1. Books we used.

\begin{tabular}{cccc}
\hline grades & Students' book & Teachers' book & Workbooks \\
\hline $\mathrm{A}^{\prime}$ & 6 & 6 & 4 \\
$\mathrm{~B}^{\prime}$ & 8 & 5 & 8 \\
$\mathrm{C}^{\prime}$ & 15 & 10 & 12 \\
$\mathrm{D}^{\prime}$ & 10 & 5 & 9 \\
$\mathrm{E}^{\prime}$ & 17 & 14 & 12 \\
$\mathrm{ST}^{\prime}$ & 12 & 10 & 11 \\
Total & 68 & 50 & 56 \\
\hline
\end{tabular}


tsiggana" (The Gypsy Nun) by F. G. Lorka (Literary Anthology, fifth and six [hereinafter 5 \& 6] grade [hereinafter g], Student' Book [hereinafter SB], p. 153-154, 256-258). But only in the former people of Roma origins appear and star. Individuals and groups of Roma origin also stars in "I Kardoula" (The little Hart) by S. Filtisi (Literary Anthology, 5 \& 6 g, SB, p. 136-138) and in "Istories me filous" (Stories with friends) by H. Katsama, Language Teaching, 5 g, SB, Vol. I, p. 77-78). Finally, there are limited references to the financial, economic, social and educational problems faced by the Roma (Social and Political Education, 6 g, SB, p. 21-22, Theatre in Education, 5 \& 6 g, TB, p. 72-73 \& 200-201).

More analytically: We found one hundred nine words that refer to the Roma. Those words that the authors of the school books use are Tsigganos Tsiggana, Tsigganiko (ninety-nine times) and Gypsy (ten times). The term Roma, a word used in the last forty years to describe this portion of the population, is totally absent from the school books.

In the first four grades (A, B, C, D), there is only two references to the Roma (Music, A \& B g, TB, p. 98 and Language Teaching, D g, TB, p. 43). The remaining one hundred seven references are made to the books of the fifth and sixth grades (Table 2).

As it concerns the lessons, we found that most references to terms related to Roma groups are made in the books of Literary Anthology and Theatre in Education (Table 3).

\section{Extent of references. short or long texts}

As far as the extent of the references to Roma individuals and groups is concerned, we have made a distinction between those that Roma occupy at least half of the page and those words in a sentence of paragraph that refer to an activity related to the Roma.

In the first category, we included seven texts: 1) "Stories with Friends" Language Teaching, 5 g, SB, Vol. A, 77-78. 2) "The Little Heart” Literature Anthology, 5 \& 6 g, SB, p. 136-138. 3) "Our Friends" Gypsies, Literature Anthology, 5 \& 6 g, SB, p. 256-258. 4) "School for All”, Social and Political Education, 6 g, SB, p. 21-22. 5) "School for All”, Social and Political Education, 6 g, TB, p. 27-29. 6) "The Team", Theatre in Education, 5 g, TB, p. 72-73. 7) Project in Intercultural Education, Theatre in Education, 5 g, TB, p. 200-201.

Table 2. References to Roma.

\begin{tabular}{cccc}
\hline grades & Student's book & Teacher's book & Workbooks \\
\hline 1 & 0 & 0 & 0 \\
2 & 0 & 1 & 0 \\
3 & 0 & 0 & 0 \\
4 & 0 & 1 & 0 \\
5 & 65 & 31 & 0 \\
6 & 6 & 6 & 0 \\
Total & 70 & 39 & 0 \\
\hline
\end{tabular}


Table 3. References to Roma by lesson.

\begin{tabular}{|c|c|c|c|c|}
\hline Grade & Student's book & $\mathrm{Nu}$ of references & Teacher's book & $\mathrm{Nu}$ of references \\
\hline $1 \& 2$ & & & music & 1 \\
\hline 4 & & & Language teaching & 1 \\
\hline 5 & Theatre in Education & 9 & Theatre in Education & 31 \\
\hline 5 & Religious studies & 1 & & \\
\hline $5 \& 6$ & Literary Anthology & 46 & & \\
\hline 5 & Music & 1 & & \\
\hline $5 \& 6$ & Art & 3 & & \\
\hline 5 & Language teaching & 3 & & \\
\hline 5 & Religious studies & 1 & & \\
\hline 6 & $\begin{array}{l}\text { Social and Political } \\
\text { Education }\end{array}$ & 2 & $\begin{array}{l}\text { Social and Political } \\
\text { Education }\end{array}$ & 3 \\
\hline 6 & Religious studies & 2 & Environmental education & 1 \\
\hline 6 & Music & 2 & music & 2 \\
\hline TOTAL & & 70 & & 39 \\
\hline
\end{tabular}

In the second category, we included simple references to the Roma (a word or a word in a sentence or a paragraph):

1) Three of those concerns the famous poem "O Dodekalogos toy Gyftou" (The Twelve Speeches of a Gypsy) written by Kostis Palamas Literature Anthology, 5 \& 6 g, SB, p. 19 \& 218 and Language Teaching, 5 g, TB, p. 43.

2) Three references concern Roma contribution to music (Music, $5 \mathrm{~g}, \mathrm{SB}, \mathrm{p}$. 46, Music, 6 g, SB, p. 45, Music, 6 g, TB, p. 67).

3) Several references concern activities within the classroom (Music, $1 \& 2 \mathrm{~g}$, TB, p. 98, Language Teaching, 5 g, SB, p. 87, Environmental Education, 6 g, TB, p. 161, Theatre in Education, 5 g, TB, p. 31-32).

4) Two references concern "race" issue (Arts, 5 g, SB, p. 69, Religious Studies, 5 g, SB, p. 121-122).

\section{Character of the references: positive or negative}

In this category, we included those references that have a positive or negative meaning concerns Roma. Our decision based on the context of the sentence that contained the term Tsiggan-os/a/iko and Gypsy. We found that most references are neutral (85), but there are several negative (16) and positive (8) (Table 4).

Manner of description: How are the Roma portrayed and how their relations with members of the other ethnic groups in Greece described.

Roma groups are a portion of Greek population that have financial and social problems. Thus, their children have special educational needs (Social and Political Education, 6 g, SB, p. 21). Some Roma individuals and groups are forced by work commitments to move to another city. As a result, their children face problems of attendance during the school year (Social and Political Education, 6 g, SB, p. 21-22) and they must separate from their friends (Language Teaching, 5 g [Vol. I], SB, p. 77-78). 
Table 4. Character of the references.

\begin{tabular}{|c|c|c|c|}
\hline Book & Positive & Negative & Neutral \\
\hline Music, $1 \& 2 \mathrm{~g}$, TB & & 1 & \\
\hline Language teaching, $4 \mathrm{~g}$, TB & & & 1 \\
\hline Theatre in Educ., $5 \mathrm{~g}$, TB & 2 & 1 & 28 \\
\hline Theatre in Educ., $5 \mathrm{~g}$, SB & 1 & & 8 \\
\hline Religious studies, $5 \mathrm{~g}$, SB & & 1 & \\
\hline Literary Anthology $5 \& 6 \mathrm{~g}$, SB & 4 & 8 & 34 \\
\hline Music, $5 \mathrm{~g}$, SB & & & 1 \\
\hline Arts, $5 \mathrm{~g}, \mathrm{SB}$ & & 1 & 2 \\
\hline Language teaching, $5 \mathrm{~g}$, SB & & & 3 \\
\hline Religious studies, $5 \mathrm{~g}$, SB & & 1 & \\
\hline Religious studies, 6 g, SB & & 2 & \\
\hline Social \& Political Ed. 6 g, SB & & & 2 \\
\hline Social \& Political Ed. 6 g, TB & & & 3 \\
\hline Music, 6 g, SB & & & 2 \\
\hline Music, $6 \mathrm{~g}$, TB & 1 & & 1 \\
\hline Environmental educ. $6 \mathrm{~g}$, TB & & 1 & \\
\hline TOTAL & 8 & 16 & 85 \\
\hline
\end{tabular}

But this is not the predominant depiction of the Roma in Greek school textbooks. The authors of textbooks do not deal with these problems. On the contrary, the authors of Greek primary school textbooks neglect not only Roma harsh living conditions, but also Greek-Roma history, activities and their overall contribution to the social and economic life of the country. It is characteristic that there is not a single reference to the Roma in the school history textbooks.

We suppose that to one degree or another, school textbooks correspond to stereotypes surrounding Roma groups. The stereotype presents a folkloric "colorful" image of a husband, wife, girl, and boy of Roma origin. Most of textbooks references to Roma promote the stereotypical understanding which sees them as quaint relics of a bygone age in which people did not have such strong commitments and obligations in their lives and could wander freely-as people whose culture is very different "our own" and whose chief characteristic is a sense of carelessness, recreation (song and dance), and having a good time. So, Roma belong to a different "race" (Arts, 5 g, SB, p. 76, Religious Studies, 121); are distinguished from non-Roma (Religious Studies, $5 \mathrm{~g}, \mathrm{SB}, \mathrm{p} .122$ ) as they are wearing weird and funny clothes, which the authors of a book (Music, $2 \mathrm{~g}, \mathrm{~TB}, \mathrm{p} .98$ ) suggest for carnival uniforms. Furthermore, Roma are exotic, incompatible and happy (Literary Anthology 5 \& 6 g, SB, 153-154, 256, 258 Theatre in Educ., 5 g, SB, p. 31-32); wanderers (Social \& Political Ed. 6 g, SB, p. 21) and they live in tents and camps (Arts, 5 g, SB, p. 69, Theatre in Educ., 5 g, SB, p. 31-32, Theatre in Educ., 5 g, TB, p. 201, Environmental educ. 6 g, TB, p. 161).

At this point, we would like to highlight two issues concerning the way most 
writers of Greek primary school textbooks seem to treat Roma. First, it seems that for most of them (the writers) Roma are persons with an identity that overshadowing their individual status. Characteristically, in "Stories with friends" (Language Teaching, 5 g, SB, Vol. 1, p. 77-78) even though the texts deal with the story of the friendship of two children, the readers of the textbooks are informed of only one of their names, that of "our own" child (the Greek, Dimitris) while the girl is described only as the Gypsy girl.

Second, in most textbooks, the name Gypsy \& Tsigganos/a is not written with capital initial letter. It should be noted that in the Greek language the first letter of names indicating ethnic origin must to be written in capital letter. Most books' writers have even been misinterpreted the way the poet K. Palamas wrote the title of his poem "O Dodekalogos toy Giftou" (The Ten speeches of a Gypsy man), writing gifto, with small initial letter of the word, while the poet himself had written it in capital letters in the original edition.

\section{Discussion}

The weak presence of individuals and groups known as Roma in the school textbooks leads us to conclude that the Greek nation continues to be the sole center of interest in the Greek education system (Therianos, Katsikas, \& Fatourou, 2008). It seems that in the case of Greek Roma groups, the declarations of accepting "otherness" and respecting cultural and linguistic diversity do not correspond to the reality of everyday life in schools (Zachos, 2014). The current legislation (Law 2413/1996, art. 34) makes possible intercultural schools (schools where students of different educational, societal, and cultural backgrounds attend), but also intercultural classes or sections in public schools which would adapt the curriculum to the educational and cultural needs of their students. Despite this legislation, the curriculum has still not been enriched with additional or alternative lessons designed to accomplishing its aim (Mitakidou, Tressou, \& Daniillidou, 2009). Additionally, the educational material still has no relevance to the life of the Roma (Wilding, 2008), while the rigid school regulations constitute additional obstacles (Tsioumis, 2003) to the educational aspirations of children of Roma origin.

Hence, the linguistic, cultural, and educational characteristics of students of Roma origins fail to be explored, studied, or constructively utilized by a primary school curriculum that remains mono-cultural and ethnocentrically oriented (Papapetrou \& Vlachadi, 2006).

As our research has shown, in spite of improvements, the school textbooks which were produced according to the curriculum's specifications and subjected to strict examination by scientific committees continue to perpetuate the dominant stereotypes of Roma. Stereotypes still exist as a coherent rather than contradictory body of thought and have played an important role in shaping the debate over the need for the education of the Roma (Carter, 2002). These stereotypes are major obstacles to the educational and social inclusion of students of Roma origins, since they maintain the negative mood towards them. So, ac- 
cording to the stereotype of "nomadism", which persists, albeit in weakened form, Roma are wanderers by choice. Hence, as it is supposedly not in Roma's nature to reside permanently in the same location, they do not require government housing measures which would address one of their community's basic needs. The romantic and exotic image of Roma is maintained and reinforced, enhancing the "stereotype that the Roma do not wish to be like or near civilized people". As a result, Roma are viewed as an insubordinate "race", the members of which, free from commitments and conventions, fail to adjust to institutions and activities that require a minimal amount of discipline and focus. Even educated Greeks, like other Europeans, tend to believe that Romani children are less educable than their own children (Chronaki, 2005), while the opinion of a single individual of Roma origins that "knowledge means trouble" (Vasiliadou \& Pavli-Korre 1996) has been reproduced in many academic papers as a characteristic feature of the relationship of Roma to education.

In order to combat these stereotypes, prejudices, and racism, we believe that it is imperative that a pluralistic, multicultural curriculum be introduced which will give schools the possibility of moving beyond the formal yearly celebrations of diversity-a curriculum which is connected to everyday life and responds to the current needs of students (No name author, 1956: p. 55). A curriculum which promotes pluralism in its choice of sources so that students obtain a global rather than ethnocentric perspective of culture (Banks, 1975). Children learn better when they build on a familiar cultural basis which allows them to add new knowledge and experiences to already existing obtained structures (Bergeron, 2008). On this note, we must stress that such a curriculum must be relevant to the whole student body of a country and not only "different" students (e.g. Roma) children. This curriculum must highlight the role that these groups played not only in their local communities but also in the wider national community.

\section{Conclusion}

Our research showed that Greek Roma groups remain nearly invisible in current school textbooks. The texts referred to or presented are few and reflect negative stereotypes and prejudices. Roma image school textbooks are promoting the one which corresponds to the folkloric stereotypes of these individuals and groups (exotic men and women that are moving from place to place and always dance and sing).

Our research findings are important because they show that the promotion of peaceful coexistence of different national/ethnic/cultural groups-a stated goal of Greek educational policy-remains incomplete. When the history and the contribution of a portion of the population to the economic, social, and cultural life of a country are ignored, it sends a message to the members of that group and to other "different" groups, groups that have some different cultural elements from the majority of the population, that exactly those elements that distinguish them are problematic and should be erased. 
In our opinion, the Greek state must intervene and take initiative in combating stereotypes, prejudices, and racism, and education can play an important role in this struggle since schools and educators can influence not only their students but also local communities. They must however be equipped with suitable tools. To deal with issues arising from societal differences, a curriculum must be developed that confronts head-on issues of societal inequality and injustice; it must show the problems, activities, and accomplishments of all portions of the population, independent of class, ethnic/national origin, sex, sexual orientation, and special needs or abilities.

\section{References}

Apple, W. M. (1993). The Politics of Official Knowledge: Does a National Curriculum Make Sense? Teachers College Record, 95, 222-241.

https://doi.org/10.1080/0159630930140101

Banks, J. (1975). Ethnic Studies as a Process of Curriculum Reform (ED110377). Washington DC: ERIC Database.

Beck, B. (1996). Nation, Curriculum and Identity in Conservative Cultural Analysis: A Critical Commentary. Cambridge Journal of Education, 26, 171-198. https://doi.org/10.1080/0305764960260204

Benson, C. (2004). The Importance of Mother Tongue-Based Schooling for Educational Quality. Paris: United Nations Educational, Scientific, and Cultural Organization.

Bergeron, B. S. (2008). Enacting a Culturally Responsive Curriculum in a Novice Teacher's Classroom: Encountering Disequilibrium. Urban Education, 43, 4-28. https://doi.org/10.1177/0042085907309208

Bowen, C. C., \& Bowen, W. M. (2008). Content Analysis. In K. Yang, \& G. J. Miller (Eds.), Handbook of Research Methods in Public Administration (pp. 689-704). New York: CRC Press.

Carter, H. (2002). Race, Romanticism and Perspectives on Gypsy Education in Early Twentieth Century. Journal of Contemporary History, 5, 1-15. http://www.sussex.ac.uk/history/research/usjch/pastissues

Chronaki, A. (2005). Learning about "Learning Identities" in the School Arithmetic Practice: The Experience of Two Young Minority Gypsy Girls in the Greek Context of Education. European Journal of Psychology of Education, 20, 61-74. https://doi.org/10.1007/BF03173211

Coley, R., \& Baker, B. (2013). Poverty and Education: Finding the Way Forward. http://www.ets.org/s/research/pdf/poverty_and_education_report.pdf

Conell, R. W. (1992). Citizenship, Social Justice and Curriculum. International Studies in the Sociology of Education, 2, 133-146. https://doi.org/10.1080/0962021920020202

Cudworth, D. (2008). There Is a Little Bit More than Just Delivering the Stuff: Policy, Pedagogy and the Education of Gypsy/Traveller Children. Critical Social Policy, 28, 361377. https://doi.org/10.1177/0261018308091275

Cummins, J. (1999). Toytotites ypo Diapragmateysi (Identities under Negotiation). Athens: Gutenberg.

Demertzis, N. (1995). O Ethnikismos os Ideologia (Nationalism as Ideology). In Etairia Spoudon Neoellinikou Politismou kai Genikis Paideias (Society of Greek Culture and General Education) (Ed.), Ethnos-Kratos-Ethnikismo (Nation-State-Nationalism) (pp. 67-116). Athens: Etairia Spoudon Neoellinikou Politismou kai Genikis Paideias. 
Diamantopoulou, G., Kiosse, E., Nikolaou, G., \& Palaska, S. (1995). I Eikona tou "Allou” sta Sigxrona Sxolia Egxeiridia toy Gymnasiou (The Image of "Other" in Modern History School Textbooks) (In Greek). In S. Chatzisavidis (Ed.), Ta Sxolika Egxeiridia ton Balkanikon Xoron (School Textbooks of Balkan Countries). Thessaloniki: Kiriakidis.

Dimitras, P. (2000). Oi Igetes ton Ellinon Roma Aporiptoun ti Diethni ton Roma (Greek Roma Leaders Disapprove the International Association of Roma). http://www.greekhelsinki.gr/dikaiomatika/06/fakelos/roma/04.htm

Flouris, G. (1983). Analytiko Programma gia mia Nea Epoxi sthn Eksi (Curriculum for a New Era in Education). Athens: Grigoris.

Frangoudaki, A., \& Dragonas, T. (1997). Ti Einai I Patrida Mas (What Is Our Homeland?). Athens: Alexandria.

Freeman, D. J., Brookhart, S. M., \& Loadman, W. E. (1999). Realities of Teaching in Racially/Ethnically Diverse Schools. Feedback from Entry-Level Teachers. Urban Education, 34, 89-114. https://doi.org/10.1177/0042085999341006

Gellner, E. (1983). Nations and Nationalism. London: Blackwell.

Guy, W. (2009). Integrated Programme for the Social Inclusion of Greek Roma, Discussion Paper.

http://webcache.googleusercontent.com/search?q=cache:oMB5XKSWTMI):ec.europa.e u/social/BlobServlet\%3FdocId\%3D8324\%26langId\%3Den $+\& \mathrm{~cd}=2 \& \mathrm{hl}=\mathrm{el} \& \mathrm{ct}=\mathrm{clnk} \& \mathrm{gl}=$ gr

Halkiotis, D. (2000). I Politiki toy YPourgeiou Paideias \& Thriskeymaton gia tin Ek/si ton Roma (The Policy of the Greek Ministry of Education for the Children of Roma). In Geniki Grammateia Eksis Enilikon (General Secretariat for Adult Education) (Ed.), $O$ Rolos tis Topikis Aytodioikisis stin Eksi ton Roma (The Role of Local Government in Education of Gypsies). Athens: General Secretariat for Adult Education.

Hamilakis, Y. (2003). "Learn History!” Antiquity, National Narrative, and History in Greek Educational Textbooks. In K. S. Brown, \& Y. Hamilakis (Eds.), The Usable Padst Greek Metahistories. Oxford: Lexington Books.

Hatzisavidis, S. (2007). Oi Rom stin Istoria tis Elladas kai tou Kosmou (Roma in the History of the World and Greece). In Program I Entaksi ton Paidion Roma sto Scholeio (Integration of Roma Children in School) (pp. 39-63). Volos.

Hickling-Hudson, A., \& Ahlquist, R. (2003). Contesting the Curriculum in the Schooling of Indigenous Children in Australia and the USA: From Eurocentrism to Culturally Powerful Pedagogies. Comparative Education Review, 47, 64-89. https://doi.org/10.1086/345837

Holsti, O. R. (1969). Content Analysis for the Social Sciences and Humanities. Reading, MA: Addison-Wesley.

Ifanti, A. (2008). Policy and Curriculum Development in Greece. The Case of Secondary School Curriculum. Pedagogy, Culture \& Society, 15, 71-81. https://doi.org/10.1080/14681360601162287

Ivrideli, M. (2001). I Parousia ton Allons to Analytiko Programma toy Dimotikou Sxoleiou (The Presence of Otherness in the Curriculum in Greek Primary Education). In N. Zoukis, \& T. Mitatos (Eds.), Elliniki Ekpaideysi \& Pagkosmiopoiisi (Greek Education and Globalization).

http://www.pee.gr/wp-content/uploads/praktika_synedrion_files/pr_syn/s_nay/c/2/ibri nteli.htm

Kapsalis, A., \& Charalampous, D. (2008). Sxolika Egxiridia. Thesmiki Exelixi \& Sigxroni Provlimatiki (School Textbooks. Institutional Development and Currentproblematic). Athens: Metexmio. 
Kouloumparitsi, A. (2005). Efarmogi tis Diathematikis Proseggisis sta Programmata Spoudon sti Didaskalia kai sta Sxolika Viblia (Implementation of the Cross-Curricular Approach to Curricula in Teaching and School Books). Nea Pedeia, 116, 30-44.

Koustourakis, G. (2007). The New Educational Policy for the Reform of the Curriculum and the Change of School Knowledge in the Case of Greek Compulsory Education. International Studies in Sociology of Education, 17, 131-146. https://doi.org/10.1080/09620210701433878

Krippendorf, K. (1980). Content Analysis: An Introduction to Its Methodology. Beverly Hills, CA: Sage.

Kyuchukov, H. (2000). Transformative Education for Roma (Gypsy) Children: An Insider's View. Intercultural Education, 11, 273-280. https://doi.org/10.1080/14675980020002420

Levinson, M. P. (2005). The Role of Play in the Formation and Maintenance of Cultural Identity: Gypsy Children in Home and School Contexts. Journal of Contemporary Ethnography, 34, 499-532. https://doi.org/10.1177/0891241605279018

Lloyd, G., \& Stead, J. (2002). Including Gypsy Travelers in Education. Race Equality Teaching, 21, 21-24. https://doi.org/10.18546/RET.21.1.09

Mantouvalou, K. (2009). Equal Recognition, Consolidation or Familiarization? The Language Rights Debate in the Context of the Minority of Western Thrace in Greece. Ethnicities, 9, 477-507. https://doi.org/10.1177/1468796809345435

McCarthy, C. (1994). Multicultural Discourses and Curriculum Reform: A Critical Perspective. Educational Theory, 44, 81-98. https://doi.org/10.1111/j.1741-5446.1994.00081.x

Messing, V. (2008). Good Practices Addressing School Integration of Roma/Gypsy Children in Hungary. Intercultural Education, 19, 461-473.

Millas, H. (1991). History Textbooks in Greece and Turkey. History Workshop Journal, 21, 21-33. https://doi.org/10.1093/hwj/31.1.21

Miskovic, M. (2009). Roma Education in Europe: In Support of the Discourse of Race. Pedagogy, Culture \& Society, 17, 201-220. https://doi.org/10.1080/14681360902934442

Mitakidou, S., Tressou, E., \& Daniilidou, E. (2009). Cross-Cultural Education: A Challenge or a Problem? International Critical Childhood Policy Studies, 2, 61-74.

Mponidis, K. (1998). Ereyna ton Didaktikon Protipon sto Dimotiko Scholeio (Research of Teaching Standards in Greek Primary Education). Ph.D. Thesis, Thessaloniki: Aristotle University of Thessaloniki.

New, W., \& Merry, M. (2012). Learning Who They "Really" Are: From Stigmatization to Opportunities to Learn in Greek Romani Education. In. Z. Bekerman, \& T. Geisen (Eds.), International Handbook of Migration, Minorities and Education (pp. 623-640). London: Springer. https://doi.org/10.1007/978-94-007-1466-3_40

No name author (1956). What Kind of Curriculums Are Needed? NASSP Bulletin, 卷号, 53-194.

No name author (2005). Imaste Ellines me Provlimata (We Are Greeks with Problems). Eleytherotypia. http://archive.enet.gr/online/online_text/c=112, $\mathrm{dt}=14.10 .2005, \mathrm{id}=52865168$

North, C. E. (2006). More than Words? Delving into the Substantive Meaning(s) of "Social Justice" in Education. Review of Educational Research, 76, 507-535. https://doi.org/10.3102/00346543076004507

Papapetrou, S., \& Vlachadi, M. (2006). Diapolitismiki Eksi and Diapolitismiko Analytiko Programma (Intercultural Education and Intercultural Curriculum). In Ereynitiko In- 
stitouto Politismou \& Eksis (Research Institute of Culture and Education) (Ed.), Praktika tou Sinedriou Laikos Politismos \& Eksi (Proceedings of the Conference Popular Culture and Education). Volos.

http://www.eipe.gr/praktika/praktika/papapetrou_vlahadi.pdf

Pedagogical Institute (2001a). Diathematiko Analytiko Programma \& Analytiko Programma tis Protobathmias Eksis. Genika (Interdisciplinary Curriculum \& Curriculum of Compulsory Education. General Section).

http://www.pi-schools.gr/programs/depps/

Pedagogical Institute (2001b). Diathematiko Analytiko Programma \& Analytiko Programma tis Protobathmias Eksis. Istoria (Interdisciplinary Curriculum \& Curriculum of Compulsory Education. History). http://www.pi-schools.gr/programs/depps/

Politou, E. (1996). Tsigganoi \& Sxoleio (Roma and School). Antitetradia tis Ekpaideysis, 39-40, 63-69.

Rougheri, C. (1999). Aliens of Gypsy Descent: Romani Images in the Greek Press. Roma Rights, 4, 28-33.

Schmid, C. (2001). Educational Achievement Language-Minority Students, and the New Second Generation. Sociology of Education, 74, 71-87. https://doi.org/10.2307/2673254

Stamatopoulos, G. (2001). O Trellos tou Xoriou (The Crazy Cave). Eleftherotypia, 53.

Sykora, C., Testot-Ferry, P., \& Tanner, E. (2010). Towards Roma Inclusion. Geneva: United Nations Children's Fund (UNICEF).

Therianos, K., Katsikas, X., \& Fatourou, A. (2008). Neo Analytiko Programma \& Sxolika Egxeiridia. Ideologia \& Praktiki (New Curricula and Textobooks. Ideology and Practice).

https://manitaritoubounou.wordpress.com/2008/05/03/analytprogrammata-sxolbibliak8er-afat-xkats/

Tsiakalos, G. (2008). I Yposxesi tis Pedagogikis (The Promise of Pedagogy). Thessaloniki: Epikentro.

Tsioumis, K. (2003). O Mikros “Allos”: Meionotikes Omades stin Proscholiki Eksi(Little “Other”: Minority Groups in Pre-School Education). Thessaloniki: Zigos.

Vasiliadou, M., \& Pavli-Korre, M. (1996). I Eksi ton Tsigganon stin Ellada (The Education of Roma in Greece). Athens: General Secretary of Popular Training.

Vrettos, I., \& Kapsalis, A. (1999). Analytiko Programma (Curriculum). Athens: Ellinika Grammata.

Wilding, D. (2008). The Educational Experiences of Gypsy Travellers: The Impact of Cultural Dissonance. Reinvention: A Journal of Undergraduate Research, 1, 1-12.

Xarchakos, S. (2001). Question to Committee (E-1671/01). (In Greek) http://www.europarl.europa.eu/sides/getDoc.do?pubRef=-//EP//TEXT+WQ+E-2001-1 $671+0+\mathrm{DOC}+\mathrm{XML}+\mathrm{V} 0 / / \mathrm{EL} \&$ language $=\mathrm{EL}$

Xochellis, P. (2008). Methodologikos Odigos gia ti Xrisi Sxolikon Biblion tou Gimnasiou (Methodological Guide to Use of School Textbook of Hight School). Thessaloniki: Lithografia.

Zachos, D., \& Michailidou, A. (2014). “Others” in Textbooks: The Case of Greek Sixth Grade's History Textbook. Theory in Action, 7, 1-25. https://doi.org/10.3798/tia.1937-0237.14016

Zachos, D., \& Panagiotidou, A. (2016). Parents' of Roma Origins Perception for the Education of Their Offspring. In Proceedings of International Conference: Mobilities, Transitions, Transformations: Intercultural Education at the Crossroads. Budapest, 5-9 September. 
Zachos, D. (2007). Ekpedeysi \& Cheirafitisi (Education and emancipation). Thessaloniki: Epikentro.

Zachos, D. (2009). Citizenship, Ethnicity and Education in Modern Greece. Journal of Modern Greek Studies, 27, 131-155. https://doi.org/10.1353/mgs.0.0054

Zachos, D. (2011b). Opseis tis Koinonikis Istorias ton Romikon Omadon tou Nomou Serron kai tis Schesis tous me tin Episimi Eksi tou Ellinikou Kratous (1880-1940) (Aspects of the Serres Prefecture Roma Groups' Social History and Their Relationship with the Official Education of the Greek State (1880-1940). To Bima ton Koinonikon Epistimon, 60, 233-246.

Zachos, D. (2012). Institutional Racism? Roma Children, Local Community and School Practices. Journal for Critical Education Policy Studies, 10, 53-66. http://jceps.com/index.php?pageID=article\&articleID $=240$

Zachos, D. (2014). Ekpedeytiki Politiki and Romikes Omades: Orismenes Kritikes Paratiriseis gia tin Periptosi tis Elladas (Educational Policy \& Roma Groups: Some Critical Comments in the Case of Greece). Comparative and International Education Review, 22, 129-143.

Zachos, D. (2017). Teachers' Perceptions, Attitudes and Feelings towards Pupils of Roma Origin. International Journal of Inclusive Education, 21, 1-17. https://doi.org/10.1080/13603116.2017.1326176

Zachos, D. (2011a). Sedentary Roma (Gypsies): The Case of Serres (Greece). Romani Studies, 21, 23-56. https://doi.org/10.3828/rs.2011.2

Zambeta, E. (2000). Religion and National Identity in Greek Education. Intercultural Education, 11, 145-156. https://doi.org/10.1080/713665239

Submit or recommend next manuscript to SCIRP and we will provide best service for you:

Accepting pre-submission inquiries through Email, Facebook, LinkedIn, Twitter, etc. A wide selection of journals (inclusive of 9 subjects, more than 200 journals)

Providing 24-hour high-quality service

User-friendly online submission system

Fair and swift peer-review system

Efficient typesetting and proofreading procedure

Display of the result of downloads and visits, as well as the number of cited articles

Maximum dissemination of your research work

Submit your manuscript at: http://papersubmission.scirp.org/

Or contact ce@scirp.org 